\title{
MINORITY, FOREIGN AND NON-NATIVE LANGUAGES IN SERBIA'S LINGUISTIC EDUCATIONAL POLICY: DESTINIES AND INTERSECTIONS
}

\begin{abstract}
Језици националних мањина (у исто време и регионални језици), српски језик као нематерњи језик, „страни језици“, итд., имају различите статусе у образовном систему Србије и предвиђају се различити облици за њихову наставу.

У овом раду, где су у овим подобластима образовне језичке политике сагледани са тачке гледишта критичке социолингвистике и анализе државне политике, динамика њиховог развоја од краја Другог светског рата до данас подвргнута је компаративној анализи, превасходно у оквиру обавезног образовања, а корени те политике су размотрени, као и њене идеолошке импликације и последице. Истраживање, које обухвата преглед историјских и идеолошких основа за стање у овој области у различитих периодима, открива повремене тензије, као и повремене и мање познате (да будемо прецизнији, у великој мери заборављене) тренутке кад су ове подобласти подстицале једна другу трагајући за иновативним решењима.
\end{abstract}

Кључне речи: мањински/страни/нематерњи језици, Србија, образовна језичка политика као државна политика, вишејезичност, критички приступ.

In Serbia, a multilingual and multicultural state, linguistic education envisages teaching various linguistic subjects, and is therefore very complex. This complexity was inherited from the time of the Federal Republic of Yugoslavia and the aim here is to show the degree of coherence / incoherence of the model, while proposing an alternative one. We will therefore begin with some brief reminders about the linguistic educational policy that is in effect today, and several historical facts that contribute to understanding the contemporary linguistic educational policy as a historically conditioned phenomenon.

\section{Language teaching in Serbia - the current state of affairs in primary-school/compulsoryeducation}

The current model of the linguistic educational policy in Serbia envisages teaching: 
- the Serbian language as the native language and the language of education;

- the Serbian language as a non-native language of members of national minorities who are being educated in their native languages;

- minority languages as native languages and the languages of education of national minorities;

- minority languages and cultures for pupils who are members of national minorities being educated in the Serbian language;

- minority languages as the languages of social communities, for pupils who are educated in Serbian or some other minority language;

- foreign languages as: a) the first foreign language throughout primary-school/compulsory education, and b) the second foreign language - an optional compulsory subject from the 5 th to the 8th grade. In both cases, the languages on offer are English, German, Russian and French, and from the end of the 20th and the early 21 st century, Italian and Spanish;

- foreign languages as optional subjects: Modern Greek, Chinese and others.

Apart from the above-mentioned subjects, there is also a specific mode of teaching - bilingual education - combining teaching in Serbian or some minority language as the language of education, the non-linguistic subjects being taught in a foreign language (for more details, see: Vučo 2009).

\section{The linguistic educational policy of Serbia: some historical and political-ideological benchmarks}

The educational system that was gradually established in the federal state after 1945 still largely formats the linguistic educational policy in Serbia. The periods that can be singled out, the priorities in education and the most essential elements of the linguistic educational policy in the sphere of minority and foreign languages will be presented in a table that encompasses the period from the end of the Second World War to the disintegration of the Socialist Federal Republic of Yugoslavia in 1990. 


\begin{tabular}{|c|c|c|c|}
\hline PERIODS & $\begin{array}{c}\text { PRIORITIES IN } \\
\text { THE SPHERE OF } \\
\text { EDUCATION }\end{array}$ & \multicolumn{2}{|c|}{$\begin{array}{c}\text { LINGUISTIC EDUCATIONAL POLICY } \\
\text { Foreign languages Minority languages }\end{array}$} \\
\hline $\begin{array}{l}\text { Period } \\
\text { immediately } \\
\text { after World } \\
\text { War Two: } \\
\text { Yugoslavia } \\
\text { follows the } \\
\text { Soviet model } \\
\text { in everything. }\end{array}$ & $\begin{array}{l}\text { - Renewing the } \\
\text { school infrastructure; } \\
\text { - fighting against } \\
\text { illiteracy; } \\
\text { - educating the female } \\
\text { population in rural } \\
\text { areas; } \\
\text { - fighting against } \\
\text { school avoidance. }\end{array}$ & $\begin{array}{l}\text { - Abolishing the teaching of German; } \\
\text { - introducing Russian as a compulsory } \\
\text { foreign language, starting from the } \\
\text { fifth form. }\end{array}$ & $\begin{array}{l}\text { - Developing the education of the constitutive peoples } \\
\text { of the federal state and ethnic minorities in their native } \\
\text { languages (this orientation was clearly expressed on } \\
\text { 10 August 1945: first through a decision passed by the } \\
\text { Temporary Council for Education of the Federal Ministry } \\
\text { of Education, then by Article } 13 \text { of the Constitution of the } \\
\text { Federal People's Republic of Yugoslavia (1946), “a union } \\
\text { of peoples with equal rights"). The ruling political } \\
\text { ideology strove to intensify the feeling of belonging } \\
\text { to Yugoslavia and was integrative in character, but it } \\
\text { recognised and encouraged the development of the } \\
\text { specific characteristics of various communities (Škiljan } \\
\text { 1988: 148). }\end{array}$ \\
\hline \multicolumn{4}{|c|}{ 1948: the conflict between the Communist Party of Yugoslavia and the Informbureau } \\
\hline $\begin{array}{l}\text { 1949: } \\
\text { The Resolution } \\
\text { of the Third } \\
\text { Plenum of } \\
\text { the Central } \\
\text { Committee of } \\
\text { the Communist } \\
\text { Party of } \\
\text { Yugoslavia } \\
\text { on Tasks in } \\
\text { Education } \\
\text { (Borba, 3rd } \\
\text { January 1950. }\end{array}$ & $\begin{array}{l}\text { - Creating a "new } \\
\text { socialist man, open, } \\
\text { universal, creative and } \\
\text { critically-minded", } \\
\text { dedicated to the idea } \\
\text { of "socialism with } \\
\text { a human face", to } \\
\text { whose development he } \\
\text { contributes and which } \\
\text { he defends; } \\
\text { - training high-level } \\
\text { professionals capable } \\
\text { of leading the country } \\
\text { towards prosperity, } \\
\text { open to any kind of } \\
\text { exchange with foreign } \\
\text { countries. }\end{array}$ & $\begin{array}{l}\text { - Including issues relating to foreign } \\
\text { language teaching in the political } \\
\text { agenda, the possibility of choosing from } \\
\text { among Russian (which is no longer a } \\
\text { compulsory foreign language), English, } \\
\text { French and German (reintroduced in } \\
\text { the curricula in the school year 1948- } \\
\text { 1949): according to some contemporary } \\
\text { historians, the right of choosing a } \\
\text { foreign language at school represents the } \\
\text { beginning of the realisation of the idea of } \\
\text { the right to cultural and artistic diversity. }\end{array}$ & $\begin{array}{l}\text { - Stimulating the learning of the languages of the } \\
\text { peoples of Yugoslavia. }\end{array}$ \\
\hline \multicolumn{4}{|c|}{ 1953: the introduction of self-management and the beginning of decentralisation and de-bureaucratisation } \\
\hline
\end{tabular}




\begin{tabular}{|c|c|c|c|}
\hline $\begin{array}{l}\text { 1954-1958: } \\
\text { The } \\
\text { preparations } \\
\text { for and the } \\
\text { realisation } \\
\text { of a great } \\
\text { reform of } \\
\text { the school } \\
\text { system. } \\
\text { The early } \\
\text { 1960's: } \\
\text { Placing } \\
\text { the school } \\
\text { system in } \\
\text { the service } \\
\text { of economic } \\
\text { development. }\end{array}$ & $\begin{array}{l}\text { - The generalisation } \\
\text { of eight-year } \\
\text { primary school; } \\
\text {-transformation of } \\
\text { secondary-school } \\
\text { education: the } \\
\text { establishment of } \\
\text { grammar schools } \\
\text { with a number of } \\
\text { educational streams; } \\
\text { - creating secondary } \\
\text { vocational } \\
\text { education that } \\
\text { enables continuing } \\
\text { education at the } \\
\text { university level; } \\
\text { - numerous } \\
\text { experimental } \\
\text { schools: first in } \\
\text { Vojvodina, starting } \\
\text { from 1954, then } \\
\text { more broadly (in } \\
\text { the school year } \\
\text { 1958/59,there were } \\
\text { around twenty such } \\
\text { schools in central } \\
\text { Serbia). }\end{array}$ & $\begin{array}{l}\text { - The entire population is encompassed } \\
\text { by primary-school education, learns } \\
\text { one foreign language (aged 11/12 to } \\
\text { 15/16); } \\
\text { - the choice of foreign languages in } \\
\text { primary schools is reduced to English } \\
\text { and Russian (starting from 1958); } \\
\text { - introducing Esperanto as an optional } \\
\text { language in the 4th form in some } \\
\text { primary schools in Vojvodina (at the } \\
\text { recommendation of UNESCO); } \\
\text { - intensifying the foreign languages } \\
\text { curriculum in linguistic streams of } \\
\text { grammar school; } \\
\text { - introducing foreign language teaching } \\
\text { in secondary vocational schools; } \\
\text { - introducing bilingual teaching in } \\
\text { Serbian and German(1956) and in } \\
\text { Serbian and French in the "Todor } \\
\text { Dukin" grammar school in Bečej; } \\
\text { - experimenting with learning at an } \\
\text { early age (Novi Sad, Beograd); } \\
\text { - experimenting with the audio-oral } \\
\text { method; } \\
\text { - 1961: the passing of the Instruction } \\
\text { on the Application of the Rules of } \\
\text { the Foreign Languages Curriculum } \\
\text { - a document whose implementation } \\
\text { almost resulted in radically abolishing } \\
\text { the teaching of German and French; } \\
\text { - 1968: a return to the policy of a } \\
\text { balanced representation of four "school } \\
\text { (foreign) languages". }\end{array}$ & $\begin{array}{l}\text { - A constant increase in the number of pupils being taught in } \\
\text { one of the minority languages, including secondary schools } \\
\text { (in Bulgarian, Czech, Slovakian, Ruthenian, Hungarian, } \\
\text { Romanian, Albanian, Turkish); } \\
\text { - establishing "territorial schools" with classes whose } \\
\text { teaching language is Serbian and classes whose teaching } \\
\text { language is a minority language. The aim was to enable } \\
\text { pupils who were national minority members to learn the } \\
\text { Serbo-Croat language better, and to enable contacts between } \\
\text { pupils of different nationalities; } \\
\text { - new curricula for teaching the Serbo-Croat language, with } \\
\text { the recommendation to use the teaching methods that are } \\
\text { applied in the teaching of foreign languages. } \\
\text { - proposal: establishing bilingual kindergartens and } \\
\text { introducing the teaching of Serbo-Croat in the 1st and } 2 \text { nd } \\
\text { grade of primary school; } \\
\text {-proposed innovations, for example, combined teaching of } \\
\text { the grammar of the Slovakian and the Serbo-Croat language } \\
\text { in the 5th and 6th form, possibly also in the 7th and 8th form } \\
\text { of primary school; } \\
\text { - in the school year 1959/60,the first experimental bilingual } \\
\text { Serbian-Hungarian classes were formed (model A in Novi } \\
\text { Sad, model B in Subotica); } \\
\text { - 1960: The Law on the Organisation and the Work of } \\
\text { Schools Where Teaching Is Conducted in the Languages } \\
\text { of National Minorities (The Official Gazette of the People's } \\
\text { Republic of Serbia, 29-60). The laws of all the federal } \\
\text { units prescribed bilingual teaching in "heterogeneous } \\
\text { communities", with the exception of Serbia, where this } \\
\text { option was left to schools and classes with pupils of the same } \\
\text { nationality; } \\
\text { - 1961: a great number of schools with Hungarian as the } \\
\text { teaching language followed the recommendation and } \\
\text { introduced the teaching of Serbo-Croat in the 1st and the } 2 \text { nd } \\
\text { grade of primary school. }\end{array}$ \\
\hline
\end{tabular}




\begin{tabular}{|c|c|c|c|}
\hline $\begin{array}{l}\text { 1974-1990: } \\
\text { Fear of a new } \\
\text { social revolt } \\
\text { of the young }\end{array}$ & $\begin{array}{l}\text {-A reform of } \\
\text { secondary- } \\
\text { school education } \\
\text { by introducing } \\
\text { vocational } \\
\text { education: the same } \\
\text { curriculum for all } \\
\text { secondary-school } \\
\text { pupils in the } 1 \text { st and } \\
\text { the } 2 \text { nd grade, in the } \\
\text { 3rd and the } 4 \text { th grade } \\
\text { they are trained for a } \\
\text { particular profession. }\end{array}$ & $\begin{array}{l}\text { - Weakening of the position of } \\
\text { foreign languages in the curriculum } \\
\text { of secondary schools, with the } \\
\text { exception of the streams for } \\
\text { translators. }\end{array}$ & $\begin{array}{l}\text { - Introducing the obligatory teaching of "the language } \\
\text { of the social community". }\end{array}$ \\
\hline
\end{tabular}




\section{Linguistic education: convergences and divergences between linguistic subjects (a brief overview)}

In order to ascertain the degree of symmetry between the linguistic subjects referred to at the beginning of this paper, we compared the following categories:

- the status of a subject,

- the curriculum,

- the elements of the aims and the concept of the curriculum.

Our analysis showed that the greatest degree of convergence could be observed in the case of the subjects The Native Language of National Minorities and The Serbian Language as the Native Language: in both cases, those were compulsory subjects, with an identical curriculum, the aim and the concept of which was first of all the development and cultivation of the national identity (the autocentric model, according to which language is one of the essential elements of identity/Škiljan 1988: 96/). The genesis of this area of the linguistic educational policy can be followed even before 1945, to put it more precisely, from 1926, when, at the Third Congress of the Communist Party in Vienna, the call was made "to introduce compulsory education in the native language at the expense of the state". The above-mentioned convergences, therefore, represent a constant in the post war period to the present day, even though in 1990 the political ideology within the framework of which this concept came into being was abandoned. The number of languages in which members of national minorities could be educated has not significantly increased over the last decade: in the Primary School Curriculum from 2004, the languages included were Albanian, Bulgarian, Hungarian, Romanian, Ruthenian, Slovakian and Croatian (The Rule Book of the Curriculum for the 1st and the 2nd Form of Primary-school Education, The Official Gazette of the Republic of Serbia, The Education Gazette no. 10/2004); to these languages the curriculum for the Bosniak language has been added subsequently (in 2013 for the 1st and the 5th form, in 2014 for the 2 nd and the 6th form, etc.).

One can observe a certain symmetry between the subject The Language and Culture of National Minorities and the above-mentioned sub- 
jects (The Serbian Language as the Native Language and The Native Languages of National Minorities) only on the level of the goal, which is, in both cases, improving the knowledge of the native language for the purpose of strengthening national identity.

The Serbian Language as a Non-native Language, The Language and Culture of National Minorities, Minority Language as the Language of the Social Community and Foreign Language have the identical curriculum today. All these subjects are taught two lessons per week, which is the minimal number of lessons that can be assigned to a subject. In the case of other categories, there are considerable differences:

- The Serbian Language as a Non-native Language and Foreign Language have the status of a compulsory subject, whereas The Language and Culture of National Minorities and Minority Language as the Language of the Social Community are optional subjects; during the course of the last decade, however, in the case of the subject The Language and Culture of National Minorities, there has been a significant increase in the number of languages: the Curriculum for the 1st and the 2nd form from 2004 comprised Hungarian, Roma, Romanian, Ruthenian, Slovakian and Croatian; the corresponding Curriculum from 2014 comprises the same languages, to which have been added the Bunjevac dialect, the Czech and the Macedonian language; from the 5th grade onward, the teaching of the Bosniak and the Ukrainian language is also envisaged; we should also point out that the subject The Language of the Social Community had the most unstable status during the period studied: most often it was optional (as it is today), but there were also prolonged periods when it was compulsory; concerning this issue, during the course of our research we observed that the status of that subject was comparatively weaker when the educational system was more centralised;

- the goals of teaching differ greatly, both when it comes to school subjects and in terms of historical periods, which is explained through the various functions that those languages have in Serbia: thus, for example, at the time of the Socialist Federal Republic of Yugoslavia (SFRY), the aim of the subjects The Serbo- 
Croat Language (as a non-native language) and The Language of the Social Community showed clear signs of ideological-political influence - strengthening the "brotherhood and unity" of the peoples and national minorities of Yugoslavia and ensuring the same opportunities for further education and professional advancement; after 1990, the goals of The Serbian Language as a Non-native Language became, we would say, minimalist: on the one hand, that subject was now supposed to develop "tolerance", and also to ensure the possibility of further education, easier access to employment; in the case of the subject Foreign Language (both the first and the second one), insistance was placed, as in the past, on functional goals - developing the ability to communicate in the given language, even though educational goals were not lacking either - developing tolerance, openness towards other peoples and cultures and the like. The fact that the educational system offers as "foreign" languages only those of politically powerful states, the founders of great civilisations (English, German, Russian and French, and from the beginning of the 21 st century also Italian and Spanish) points to the fact that an alocentric model is being applied. According to some authors, this model is based on "the ideology of the unequal value of languages" (Beacco 2001: 1, 2)

\section{Unexpected intersections in the past: the dynamic 1950's}

Despite the very different linguistic ideologies on the basis of which these models were created, certain convergences and mutual influences of the subjects The Serbo-Croat Language as a Non-native Language, The Language of the Social Community and Foreign Language can be observed during the brief but dynamic four-year period from 1954 to 1958. As our research shows, it is the only period before the reform of 20012004 when there were institutionalised attempts in Serbia's linguistic educational policy aiming at intersecting experiences acquired within the framework of different linguistic subjects, attempts at opening them up to one another, that is, a kind of understanding- naturally, only in its initial 
phase - of linguistic education as a holistic form of education.Let us point out that the cases we describe are mostly encountered in Vojvodina, whose Institute for the Advancement of Teaching was officially entrusted with the task of preparing a document on the education of national minorities by the Federal Commission for the Reform of the Educational System in 1955.

The said period has a twofold significance for linguistic education in our country:

- it was a preparatory period of the reform of the educational system, whose implementation in all the republics of the federal state would be ensured through The General Law on the Educational System of 1958, many regulations of which are still in effect in Serbia; during that preparatory period, a considerable number of pedagogical experiments were introduced in schools, among other things in the domain of language teaching;

- on the other hand, in the case of foreign languages, it was a period when the idea formulated in one of the most important politicalideological documents of the time, The Resolution of the Third Plenum of the Central Committee of the Communist Party of Yugoslavia, passed on 31st December 1949, was to be realised.

Chronologically speaking, one of the first experiments in that period was the introduction of bilingual teaching: in 1956, in the "Todor Dukin" grammar school in Bečej, the teaching of geography in German was initiated, and the very next year it was done in French. After that, year after year, bilingual teaching expanded, so that a combination of Serbo-Croat as a non-native tongue and one of the minority languages was applied (the models referred to in footnotes 7 and 8 of this paper). After these positive experiences, the possibility of bilingual teaching was regularly mentioned in Serbian laws (although it is very rarely implemented in practice). Article 26, paragraph 2 of the Law on Primary School from 1959 (The Educational Gazette of the People's Republic of Serbia nos. 7, 8 and 9)states: "In areas inhabited by national minorities and the population of Yugoslav nationalities, classes and schools with bilingual teaching shall be founded in accordance with the local possibilities."

Another form of mutual influence of different linguistic subjects is evident in the phenomenon of starting learning at an increasingly early 
age: first of all of a foreign language - in the school year 1957/58, in Novi Sad, the experiment of teaching German and French from the 4th grade of primary school was initiated (the teaching of a Foreign Language otherwise started from the 5th form), and soon afterwards Serbo-Croat as a Non-native Language was introduced in the 1st form (otherwise, its teaching then began in the 3rd form). (As early as 1961, a large number of primary schools with Hungarian as the teaching language followed the recommendation of the Institute for Professional and General Education of the Autonomous Province of Vojvodina and introduced the teaching of Serbo-Croat as a Non-native Language from the 1 st or from the 2 nd form.)

Even though they are little known, influences are also observable at the level of the methodology of teaching: since the teaching of SerboCroat as a Non-native Language was still inefficient to a large degree (despite a new curriculum), in 1957 teachers who were teaching this subject were advised to apply teaching methods that had proven themselves to be effective in the teaching of foreign languages: "Teachers of Serbo-Croat [as a non-native language, Lj. Đ.] in those schools were recommended to primarily use those contemporary methods and teaching aids whose value and efficiency had been proven in the teaching of living foreign languages" (Melvinger 1957: 271).

\section{Languages exposed to social tensions - some other parallels...}

The analysed model of the linguistic educational policy, created for the most part, as we have already pointed out, at the time of the SFRY, still did not achieve the political-ideological goal of developing "brotherhood and unity". Moreover, a lot of the political tensions in the past were manifested precisely by way of refusing to learn a particular language. As regards Serbian as a Non-native Language, as the best-known example from the relatively recent past, we shall offer Kosovo Albanians, who, in the 1990's, not only did not want to learn the Serbian language (just as Kosovo Serbs did not want to learn Albanian as the language of the social community), but also, by refusing to attend schools implementing the curricula of the Republic of Serbia, established a parallel educational system. This was one of the first steps towards establishing the "state" of Kosovo, "independent" from Serbia, still unrecognised by a number of states and the United Nations. 
More recently, the tensions that the public has been regularly informed about through the media are cases of abuse of "ignorance" of the Serbian language in court proceedings where members of national minorities are on trial. With a view to prolonging the trial (and possibly exceeding the legal deadline for prosecution), some of them in such situations abruptly "lose the ability to communicate with people they communicated with until yesterday (and still do outside the court)", as pointed out by Miodrag Jovanović, lecturer at the Faculty of Law of Belgrade University, where he teaches the subject Minority Rights.

Concerning the teaching of The Language of the Social Community, the public rarely discusses what is confirmed by both research and experience, namely, that there is very little interest among pupils who are native Serbian speakers in learning minority languages: "In the lower forms of primary school there is some response to speak of, but it decreases in the higher forms. There are no textbooks either, for the subject has in effect not been recognised by the Ministry" says Sárosi Gabriella, the principal of the primary school "Stevan Sremac" in Senta, a member of the Managing Board of the Institute of Pedagogy of Vojvodina.

The attempt to resolve the above-mentioned problems (and others, for example, those pertaining to providing professional minority languages staff for certain subjects) by passing, in November 2015, the Rule Book on the Closely Defined Conditions for Realising Bilingual Teaching, which was supposed to regulate teaching in Serbian and in some "foreign" language, as well as teaching in Serbian and in some "minority" language, did not bear fruit because some national minority councils opposed its application in schools where teaching is conducted in one of the minority languages.

\section{The alternative: developing the multilingual competences of all the pupils of Serbia}

For quite a number of years, a part of the scientific community in Serbia that deals with issues pertaining to the linguistic educational policy has been offering alternative solutions, among which undoubtedly the best worked-out was created in the reform process of 2001-2004 (the Commis- 
sion for the Development of the Curriculum, the Commission for the Educational Sphere of Language, Literature and Communications): it was then that the goals of this area of education were formulated, as well as the educational outcomes in terms of educational cycles, and also the goals and outcomes of subjects in terms of educational cycles: The Native Language, The Serbian Language as a Non-native Language, Foreign Language as a Basic Subject, The Second Foreign Language, Classical Languages (The Rule Book on the General Foundation of the Curriculum, The Official Gazette of the Republic of Serbia, The Educational Gazette no. 5 / 2004) As is well known, however, that concept was not realised, and its opponents did not desist from resorting to lies in order to discredit it (Semić 2008).

Even after the cessation of the reform, scientific texts - books, articles - are still published, and they contain an argumentative critique of the existing model and offer alternative solutions. Let us mention, for example, Filipović (2009: 65-68; 2011: 237-239), Đurić (2016: 504-506) etc.

In view of the fact that the model now in effect - where in, despite rare fruitful intersections of which we have spoken a little, each linguistic subject remains isolated in relation to the others -does not produce satisfactory results today, just as it failed to do in the past. What could be offered as an alternative is linguistic education that would lead to the acquisition of real and provable multilingual competence of all the pupils in Serbia, a competence that we understand, in keeping with the definition of the Council of Europe, as "[...] the right and need of each person to use, throughout his/her life, the languages that he/she identifies as necessary, significant and relevant for developing his/her own identity, for professional, educational and personal purposes, and/or for basic communication" (Filipović 2011: 237).

Instead of five kinds of linguistic subjects unconnected among themselves, it would be useful to have them classified in two groups in the educational system, which would have closely connected goals, and whose teaching would be based on similar, mutually adjusted methodological foundations:

a. The Native Language (Serbian or one of the national minority languages) and The Language and Culture of a National Minority - with a view to cultivating the national identity and the native language and culture, but with a significant introduction of elements of pragmatic and intercultural competence; 
b. Living Languages (The Serbian Language as a Non-native Language, Foreign Languages, The Languages of the Social Community), whose teaching would be aimed, first of all, at the acquisition of communicative competence (also including intercultural competence), and would be organised at several levels adjusted to the Common European Framework for Living Languages.

Such an approach, which, in the case of languages under b),would primarily develop the communicative function - placing the political-symbolic one in the background - would stimulate a greater degree of interest on the part of pupils from national minorities to learn Serbian, and interest of pupils who are native Serbian speakers in learning national minority languages.

Multilingualism as a model of linguistic educational policy - of whose advantages (and shortcomings) we have written elsewhere (Đurić 2016: 402, 403) - represents a great challenge for the educational authorities of a state where public policies, especially linguistic ones, are often enough based on ideological fallacies. Still, that model is the only one that ensures fairness, flexibility, social cohesion, but which is also materially profitable, both for the individual and for the economy of the broader social community (Grin et al. 2009: 44, 45).

\section{References:}

Beacco 2001: Beacco, Jean-Claude, "Les idéologies linguistiques et le plurilinguisme", in: Le Français dans le Monde, p. 314 (pagination based on the electronic form of the text, available at www.observatoireplurilinguisme.eu; accessed in April 2013).

Čehak 1961: Čehak, Julija, "Sličice iz života i rada dvojezičnih odeljenja [Pictures from the Life and Work of Bilingual Classes]", Pedagoška stvarnost 4/1961.

Đurić 2016: Đurić, Ljiljana, Strani jezici u obrazovnoj politici Srbije [Foreign Languages in the Educational Policy of Serbia], Beograd: Filološki fakultet Univerziteta u Beogradu.

Filipović2009:Filipović, Jelena, Moć reči. Ogledi iz kritičke sociolingvistike [The Power of Words. Essays in Critical Sociolinguistics]. Beograd: Zadužbina Andrejević. 
Filipović 2011:Filipović, Jelena, “Evropski projekat višejezičnosti i jezičke (obrazovne) politike [The European Project of Multilingualism and Linguistic (Educational) Policy]". Reči, 4/2011, pp. 228-242.

Grin etal. 2009: Grin, François, Sfreddo, Claudio, Vaillancourt, François, Langues étrangères dans l'activité professionnelle ("LEAP”). Rapport final de recherche. Programme national de recherche 56 Multilinguisme et compétences linguistiques en Suisse. Available at: www.unige.ch. Accessed in December 2012.

Melvinger 1957: Melvinger, Zlatko, "O sistemu savlađivanja srpskohrvatskog jezika u školama nacionalnih manjina [On the System of Mastering the Serbo-Croat Language in National Minority Schools]", Pedagoška stvarnostno. 4 / 1957.

Semić 2008: Semić, Marijana, Odnos štampanih medija prema reformi obrazovanja [The Attitude of the Printed Media to the Educational Reform]2001/2007, Beograd: Beo štampa.

Škiljan 1988: Škiljan, Dubravko, Jezična politika [The Linguistic Policy]. Zagreb: Naprijed.

Točanac 1990: Točanac, Dušanka, "Učenje jezika u SFR Jugoslaviji [Learning Languages in theSFR Yugoslavia]”, in: Bekićetal. (ed), Zbornik radova sa Prve konferencije Živi jezici, Novi Sad: Institut za strane jezike i književnosti Filozofskog fakulteta Univerziteta u Novom Sadu, pp. 5-16.

Vučo 2009: Vučo, Julijana, “O jeziku obrazovanja manjinskih zajednica $\mathrm{u}$ Srbiji [On the Language of Education of Minority Communities in Serbia]", in: Hadži etal.(ed), Status tujih in drugih jezikov: med politiko in stvarnostji. Jezikovna situacija v novonastalih drzavah bivse Jugoslavije, Ljubljana: Filozofska fakulteta, pp.249-265.

\footnotetext{
Abstract

The languages of national minorities (at the same time regional languages as well), Serbian as a non-native language, "foreign languages" etc. have different statuses in the educational system of Serbia, and various modes are envisaged for their teaching.

In this paper these subareas of the linguistic educational policy are examined from the point of view of critical sociolinguistics and an analysis of public policies. The dy- 
namics of their development from the end of World War Two to the present day are subjected to a comparative analysis, primarily within the framework of compulsory education, and the roots of this policy are reviewed, as are its ideological implications and consequences. The survey, which includes reviewing the historical and ideological basis of the state of affairs in this area in different periods, reveals occasional tensions but also the infrequent and lesser known (to put it more precisely, largely forgotten) moments when these subareas, mutually stimulated one another searching for innovative solutions.

Keywords: minority/foreign/non-native languages, Serbia, the linguistic educational policy as a public policy, plurilingualism, a critical approach.

\section{Biographical statement}

LJILJANA ĐURIĆ, Ph.D., is an Assistant Professor at the Faculty of Philology, University of Belgrade. Until the end of 2004, she worked at the Ministry of Education of the Republic of Serbia as a coordinator for foreign languages in formal education, where she was in charge of curriculum design, design and implementation of teacher training programmes and textbook evaluation. From 2002 to 2004 she was a member of the curriculum development team, a body which coordinated the overall primary and secondary curricular reform in Serbia. She has co-authored several textbooks for French as a foreign language, and published papers and translations in the area of education and pedagogy. She has also designed a number of foreign language curricula and several experimental projects for foreign language instruction.

Over the past decade, Ljiljana Djuric's work has been focused on two parallel, complementary research areas: the methodology of foreign language teaching, in particular French, and sociolinguistic and political perspectives of educational language policies. In both main focus areas, she has implemented a similar methodology, using aspects of diachrony and synchrony, as well as pointing out contemporary and innovative phenomena. Her research, especially studies of educational language policies, is conceived within the critical paradigm.

E-mail: djuricz@sbb.rs 